\title{
Effects of Composition and Amount of Liquid Phase on Mechanical Properties of Bioactive Cement Based on $\mathrm{CaO}-\mathrm{SiO}_{2}-\mathrm{P}_{2} \mathrm{O}_{5}$ Glass Powders
}

\author{
Satoru YOSHIHARA, Fumiaki MIYAJI, Tadashi KOKUBO, Naomi NISHIMURA*, \\ Takao YAMAMURO* and Takashi NAKAMURA** \\ Faculty of Engineering, Kyoto University, Sakyo-ku, Kyoto-shi 606-01 \\ *Faculty of Medicine, Kyoto University, Sakyo-ku, Kyoto-shi 606-01 \\ **Research Center for Biomedical Engineering, Kyoto University, Sakyo-ku, Kyoto-shi 606-01
}

\section{$\mathrm{CaO}-\mathrm{SiO}_{2}-\mathrm{P}_{2} \mathrm{O}_{5}$ 系ガラス粉末を用いた生体活性セメントの機械的性質に対する 液相の組成と量の影響}

\author{
吉原 聡・宮路史明・小久保 正・西村直巳*。山室隆夫* 中村孝志** \\ 京都大学工学部, 606-01 京都市左京区吉田本町 \\ *京都大学医学部，606-01 京都市左京区聖護院河原町 54 \\ **京都大学生体医療工学研究センター，606-01 京都市左京区聖護院河原町 53
}

[Received June 1, 1994; Accepted August 30, 1994]

\begin{abstract}
Bioactive cement which can set in a few minutes and bond to living bone is obtained by mixing $\mathrm{CaO}-\mathrm{SiO}_{2}-$ $\mathrm{P}_{2} \mathrm{O}_{5}-\mathrm{CaF}_{2}$ glass powders with ammonium phosphate solution. The mechanical strength of the cement has been investigated as a function of phosphate ion concentration and $\mathrm{pH}$ of the ammonium phosphate solution and powder to liquid ratio. A glass powder with a composition $\mathrm{CaO}$ 47.1, $\mathrm{SiO}_{2} 35.8, \mathrm{P}_{2} \mathrm{O}_{5}$ 17.1, $\mathrm{CaF}_{2} 0.75$ in mass ratio was mixed with ammonium phosphate solution, placed in $100 \%$ humidity at $37^{\circ} \mathrm{C}$ for $1 \mathrm{~h}$ and immersed into a simulated body fluid (SRF). The compressive strengths of the cements soaked in SBF for $23 \mathrm{~h}$ increased with increase in phosphate ion concentration and $\mathrm{pH}$ of the ammonium phosphate solution and in powder to liquid ratio. It has been found that the cements using ammonium phosphate solution with $\mathrm{pH}$ 7.4 and phosphate ion concentration of $3.7 \mathrm{M}$ give the highest compressive strength of $58 \mathrm{MPa}$. It has been indicated that for the fixed ratio of powder to liquid, the compressive strength of the cement soaked in SBF increases with increasing amount of the hydroxyapatite layer formed at the intergranular spaces in the glass powders.
\end{abstract}

Key-words : $\mathrm{CaO}-\mathrm{SiO}_{2}-\mathrm{P}_{2} \mathrm{O}_{5}$ glass, Ammonium phosphate solution, Bioactive cement, Apatite, Calcium ammonium phosphate hydrate

\section{Introduction}

Development of a bioactive cement which can set within a few minutes, give high mechanical strength and bond to living bone without giving any adverse effects to the surrounding tissues is required in dentistry, oral surgery, orthopedic surgery, plastic surgery, brain surgery, otorhinolaryngology etc.

Various attempts have been made for obtaining such bioactive cement by using crystalline calcium phosphate such as tetracalcium phosphate $\left(\mathrm{Ca}_{4}\right.$
$\left.\left(\mathrm{PO}_{4}\right)_{2} \mathrm{O}\right)$, dicalcium phosphate $\left(\mathrm{CaHPO}_{4}\right)$ and $\alpha$ tricalcium phosphate $\left(\mathrm{Ca}_{3}\left(\mathrm{PO}_{4}\right)_{2}\right) .{ }^{1)}$ The resultant cements, however, still have problems in setting time, mechanical strength, stability in the body and/ or reactions with living tissues. Recently the present authors showed that a mixture of a $\mathrm{CaO}-\mathrm{SiO}_{2}-\mathrm{P}_{2} \mathrm{O}_{5}$ glass powder with an ammonium phosphate solution gives a bioactive cement which sets within $4 \mathrm{~min}$, hardens up to $80 \mathrm{MPa}$ in the compressive strength in the living body as well as in simulated body fluid (SBF) within $3 \mathrm{~d}$ and bonds to the living bone by 4 weeks without giving inflammatory reaction. ${ }^{2)-4)}$ Effects of composition and size of the glass powder on mechanical properties of the cement were reported elsewhere.5)

In the present study, the effects of the phosphate ion concentration, $\mathrm{pH}$ and content of the ammonium phosphate solution on properties of the bioactive cement were systematically investigated. The results were discussed in terms of the microstructure.

\section{Experimental}

2.1 Preparation of glass powder

A powder mixture of the nominal composition of $\mathrm{CaO}$ 47.1, $\mathrm{SiO}_{2}$ 35.8, $\mathrm{P}_{2} \mathrm{O}_{5} 17.1$ and $\mathrm{CaF}_{2} 0.75$ mass ratio was prepared from reagent-grade chemicals of $\mathrm{CaCO}_{3}, \mathrm{SiO}_{2}, \mathrm{Ca}_{2} \mathrm{P}_{2} \mathrm{O}_{7}$ and $\mathrm{CaF}_{2}$. The mixture was put into a platinum crucible, melted in a $\mathrm{SiC}$ furnace at 1500 to $1600^{\circ} \mathrm{C}$ for $4 \mathrm{~h}$ and quenched between watercooled steel rollers, forming thin glass ribbons. These glass ribbons were pulverized into fine powders with an average size of about $5 \mu \mathrm{m}$ using an alumina ball mill.

2.2 Preparation of ammonium phosphate solution

Two series of ammonium phosphate solutions were prepared, in which phosphate ion concentra- 
tion and $\mathrm{pH}$ were varied, respectively; the first had the fixed $\mathrm{pH} 7.4$ with different phosphate ion concentration, the second did the fixed phosphate ion concentration of $3.7 \mathrm{M}$ with different $\mathrm{pH}$. All these solutions were prepared by dissolving reagent-grade diammonium hydrogen phosphate $\left(\left(\mathrm{NH}_{4}\right)_{2} \mathrm{HPO}_{4}\right)$ and ammonium dihydrogen phosphate $\left(\mathrm{NH}_{4} \mathrm{H}_{2} \mathrm{PO}_{4}\right)$ with different total amounts at a fixed ratio or different ratios at a fixed total amount into ion-exchanged water.

\subsection{Preparation of cement}

The glass powders and the ammonium phosphate solution were homogeneously mixed on a glass plate at a powder to liquid $(P / L)$ ratio of $1 \mathrm{~g} / 0.5 \mathrm{ml}$ to 1 $\mathrm{g} / 0.6 \mathrm{ml}$. After mixing for $30 \mathrm{~s}$, the paste was loaded into a $12-\mathrm{mm}$ high PMMA mold with a $6-\mathrm{mm}$ internal diameter. The top and bottom sides of the mold were covered with two glass plates, tightly nipped by a " $\mathrm{C}$ "-clamp and stored in $100 \%$ humidity at $37^{\circ} \mathrm{C}$.

\subsection{Simulation of body reaction}

After $1 \mathrm{~h}$, the cement was removed from the mold and soaked into $20 \mathrm{ml}$ of a simulated body fluid $(\mathrm{SBF})^{6)}$ with ion concentrations nearly equal to those of human blood plasma, ${ }^{7)}$ as shown in Table 1, in order to simulate the reaction of the cement in the living body. The fluid was buffered at $\mathrm{pH} 7.25$ with $50 \mathrm{mM}$ tris (hydroxymethyl)aminomethane $\left(\mathrm{CH}_{2}\right.$ $\mathrm{OH})_{3}\left(\mathrm{NH}_{2}\right)$ ) and $45 \mathrm{mM}$ hydrochloric acid $(\mathrm{HCl})$, and its temperature was maintained at $37^{\circ} \mathrm{C}$. This simulated body fluid can reproduce fairly precisely the reaction of bioactive glasses and glassceramics in the body. ${ }^{8)}$

\subsection{Measurement of compressive strength}

Compressive strengths of the cement just before and after soaking in SBF for $23 \mathrm{~h}$ were measured using an Instron-type testing machine at a crosshead speed of $0.5 \mathrm{~mm} / \mathrm{min}$ while the test pieces were wet. At least five measurements were repeated for each data point.

\subsection{Analyses of microstructure}

Before and after soaking in SBF, the specimens were pulverized and subjected to powder X-ray diffraction (Rigaku-Denki model RAD IIC) in order to identify the crystalline phases formed in the cement.

\section{Results and discussion}

\subsection{Compressive strength}

Figure 1 shows the compressive strengths of the

Table 1. Ion Concentrations of Simulated Body Fluid (SBF) and Human Blood Plasma

\begin{tabular}{lcccccccc}
\hline & \multicolumn{8}{c}{ Ion concentration (mM) } \\
\cline { 2 - 8 } & $\mathrm{Na}^{+}$ & $\mathrm{K}^{+}$ & $\mathrm{Ca}^{2+}$ & $\mathrm{Mg}^{2+}$ & $\mathrm{Cl}^{-}$ & $\mathrm{HCO}^{3-}$ & $\mathrm{HPO}_{4}^{2-}$ & $\mathrm{SO}_{4}{ }^{2-}$ \\
\hline SBF & 142.0 & 5.0 & 2.5 & 1.5 & 147.8 & 4.2 & 1.0 & 0.5 \\
Human plasma & 142.0 & 5.0 & 2.5 & 1.5 & 103.0 & 27.0 & 1.0 & 0.5
\end{tabular}

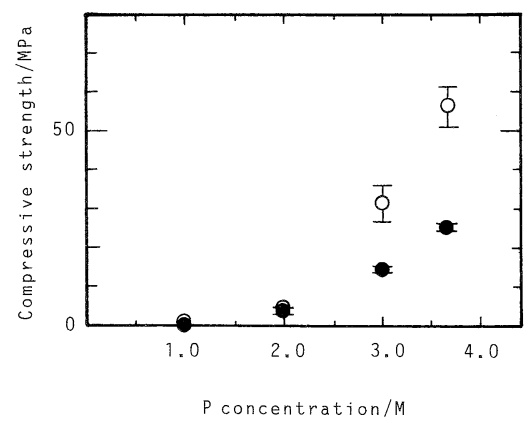

Fig. 1. Compressive strengths of the cement just before and after $(\bigcirc)$ soaking in SBF for $23 \mathrm{~h}$ as a function of phosphate ion concentration of the solutions of $\mathrm{pH} 7.4$, where $P / L$ ratio was $1 \mathrm{~g} / 0.5 \mathrm{ml}$

cement just before and after soaking in SBF for $23 \mathrm{~h}$ as a function of phosphate ion concentration of the solutions of $\mathrm{pH} 7.4$, where $P / L$ ratio was $1 \mathrm{~g} / 0.5 \mathrm{ml}$. It is found that the compressive strength of the cement increases with increasing phosphate ion concentration of the solution for both before and after soaking in SBF. This figure also shows that the strengths after soaking is higher than those before soaking, especially for the solutions with concentration higher than $2 \mathrm{M}$. The maximum strength of $58 \mathrm{MPa}$ obtained for $3.7 \mathrm{M}$ phosphate ion concentration.

Figure 2 shows the compressive strengths of the cement just before and after soaking in SBF for $23 \mathrm{~h}$ as a function of $\mathrm{pH}$ of the solutions with $3.7 \mathrm{M}$ phosphate ion concentration, where $P / L$ ratio was $1 \mathrm{~g} /$ $0.6 \mathrm{ml}$. Figure 2 indicates that the compressive strengths for both before and after soaking increase as the $\mathrm{pH}$ increases, although the change in the strength is much larger in the latter than in the former. The strengths become nearly constant up to the $\mathrm{pH}$ 7.4. The maximum strength after soaking in SBF was about $50 \mathrm{MPa}$ at $\mathrm{pH} 8.3$.

The compressive strengths of the cement just before and after soaking in SBF for $23 \mathrm{~h}$ are shown in Fig. 3 as a function of $P / L$ ratio, where the solution had 3.7 phosphate ion concentration and $\mathrm{pH} 7.4$. For all the $P / L$ ratio range, the strengths after soaking is much higher than those before soaking. The former, however, gradually decreases with decreasing $P / L$

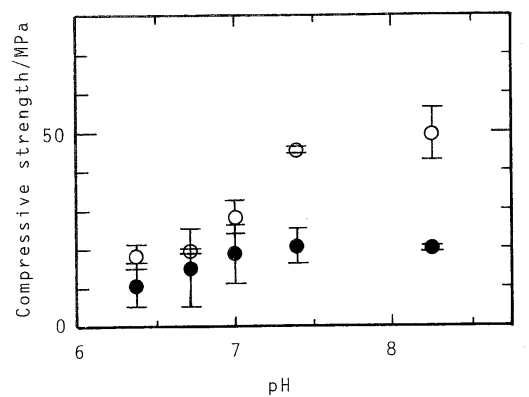

Fig. 2. Compressive strengths of the cement just before and after $(\bigcirc)$ soaking in SBF for $23 \mathrm{~h}$ as a function of $\mathrm{pH}$ of the solutions with $3.7 \mathrm{M}$ phosphate ion concentration, where $P / L$ ratio was $1 \mathrm{~g} / 0.6 \mathrm{ml}$. 


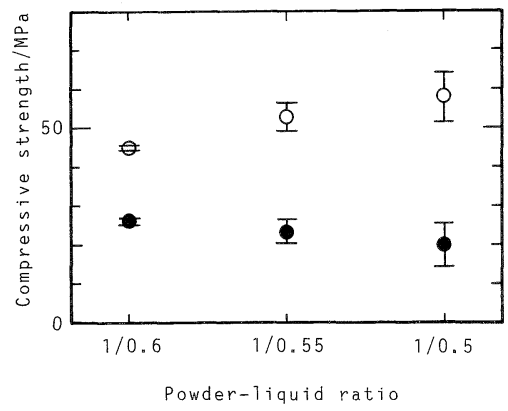

Fig. 3. Compressive strengths of the cement just before and after $(O)$ soaking in SBF for $23 \mathrm{~h}$ as a function of $P / L$ ratio, where the solutions had $3.7 \mathrm{M}$ phosphate ion concentration and pH 7.4.

ratio.

\subsection{X-ray diffraction}

Figure 4 shows the powder X-ray diffraction patterns of the cements just before and after soaking in SBF for $23 \mathrm{~h}$ as a function of phosphate ion concentration of the solutions with $\mathrm{pH} 7.4$, where $P / L$ ratio was $1 \mathrm{~g} / 0.5 \mathrm{ml}$. It is found that the glass powders mixed with the ammonium phosphate solution form the calcium ammonium phosphate hydrate $\left(\mathrm{CaNH}_{4}\right.$ $\mathrm{PO}_{4} \mathrm{H}_{2} \mathrm{O}$ ) phase only for the phosphate ion concentration higher than $2.0 \mathrm{M}$ and the amount of the phase increases with increasing phosphate ion concentration. On the other hand, when the set cement was soaked in SBF, they formed the hydroxyapatite $\left(\mathrm{Ca}_{10}\left(\mathrm{PO}_{4}\right)_{6}(\mathrm{OH})_{2}\right)$ in place of the calcium ammonium phosphate hydrate and its amounts similarly increased with increasing phosphate ion concentration. Taking the compressive strength variation into consideration, it is concluded that the larger the amount of hydroxyapatite is formed in the cements, the higher compressive strength of the cements is obtained.

Figure 5 shows the powder X-ray diffraction patterns of the cements just before and after soaking in $\mathrm{SBF}$ for $23 \mathrm{~h}$ as a function of $\mathrm{pH}$ of the solution, with
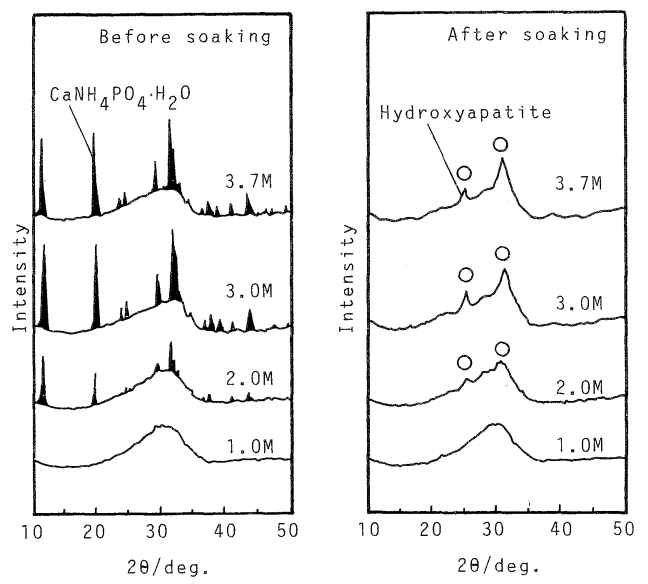

Fig. 4. Powder X-ray diffraction patterns of the cements just before and after soaking in SBF for $23 \mathrm{~h}$ as a function of phosphate ion concentration of the solution. This figure corresponds to Fig. 1.
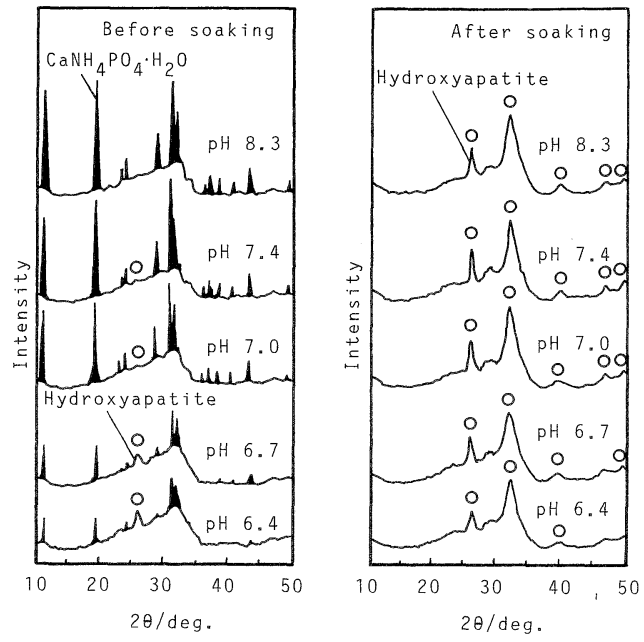

Fig. 5. Powder X-ray diffraction patterns of the cements just before and after soaking in SBF for $23 \mathrm{~h}$ as a function of $\mathrm{pH}$ of the solutions with $3.7 \mathrm{M}$ phosphate ion concentration, where $P / L$ ratio was $1 \mathrm{~g} / 0.6 \mathrm{ml}$. This figure corresponds to Fig. 2 .

$3.7 \mathrm{M}$ phosphate ion concentration, where $P / L$ ratio was $1 \mathrm{~g} / 0.6 \mathrm{ml}$. It is found that the glass powders mixed with the ammonium phosphate solution form only the calcium ammonium phosphate hydrate phase except for small amount of hydroxyapatite precipitation for the $\mathrm{pH}$ 6.4-7.4 and the amount of the former phase increases with increasing $\mathrm{pH}$. All the set cements soaked in SBF forms hydroxyapatite and the amount of the phase increases as the $\mathrm{pH}$ increases. There results suggest that the hydroxyapatite phase is formed by the reaction of the calcium ammonium phosphate hydrate with SBF.

Figure 6 shows the powder X-ray diffraction patterns of the cements just before and after soaking in SBF for $23 \mathrm{~h}$ as a function of $P / L$ ratio, where the solution had $3.7 \mathrm{M}$ phosphate ion concentration and $\mathrm{pH}$ 7.4. It is found that the glass powders mixed with the ammonium phosphate solution form the calcium ammonium phosphate phase. In addition, the small
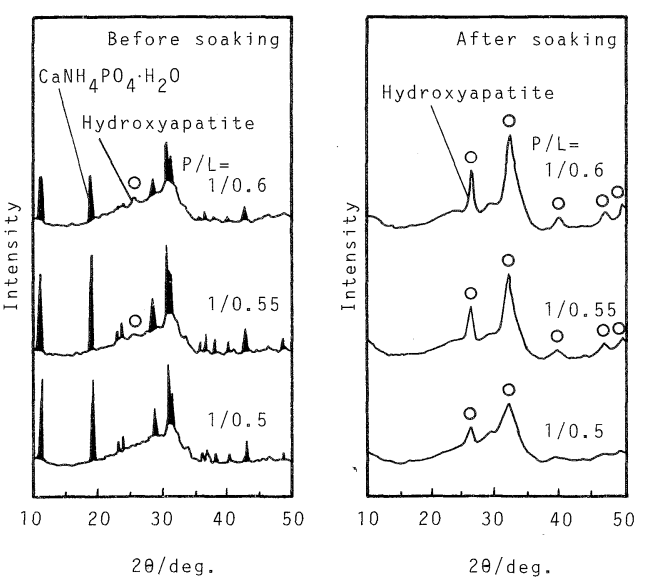

Fig. 6. Powder X-ray diffraction patterns of the cements just before and after soaking in SBF for $23 \mathrm{~h}$ as a function of $P / L$ ratio, where the solution had $3.7 \mathrm{M}$ phosphate ion concentration and $\mathrm{pH}$ 7.4. This figure corresponds to Fig. 3. 
peak corresponding to the hydroxyapatite is observed for the $P / L$ ratio of $1 \mathrm{~g} / 0.55 \mathrm{ml}$ and $1 \mathrm{~g} / 0.6$ $\mathrm{ml}$. The amount of hydroxyapatite formed in the cements soaked in SBF increases with increasing $P / L$ ratio. From the comparison of Fig. 3 with Fig. 6 , however, in this case the compressive strengths are not parallel to the amount of hydroxyapatite. The possible reason will be discussed in the following.

\subsection{Reaction process}

The short setting time, in practice a few minutes, of the cement is ascribed to the formation of calcium ammonium phosphate hydrate phase at intergranular spaces of the glass powders. ${ }^{2}$ On the other hand, the increase in the compressive strength of the cement during soaking in SBF is attributed to the formation and growth of hydroxyapatite phase in place of the calcium ammonium phosphate hydrate. ${ }^{2)}$ It can be therefore said that the strength of the cement is closely related with the amount of the hydroxyapatite layer formed in the cement.

The increase in phosphate ion concentration in the solution gives the larger amount of the calcium ammonium phosphate hydrate when the glass powder was mixed with the solution, since the phosphate ions serve as phosphorus source of the crystal phase. The larger amount of the calcium ammonium phosphate hydrate gives formation of the larger amount of the hydroxyapatite layer in SBF, to give higher compressive strength, since the hydroxyapatite is through the calcium ammonium phosphate hydrate. In the formation of the hydroxyapatite $\left(\mathrm{Ca}_{10}\left(\mathrm{PO}_{4}\right)_{6}\right.$ $(\mathrm{OH})_{2}$ ) from the calcium ammonium phosphate hydrate $\left(\mathrm{CaNH}_{4} \mathrm{PO}_{4} \mathrm{H}_{2} \mathrm{O}\right)$, the release of ammonium ions and taking up of more calcium ions are required. The required calcium ion will be supplied from those dissolved from glass powders into SBF. The formation of the hydroxyapatite in SBF is generally represented by

$$
10 \mathrm{Ca}^{2+}+6 \mathrm{PO}_{4}^{3-}+2 \mathrm{OH}^{-} \rightleftarrows \mathrm{Ca}_{10}\left(\mathrm{PO}_{4}\right)_{6}(\mathrm{OH})_{2}
$$

The Eq. (1) indicates that the increase in $\mathrm{OH}^{-}$ion concentration, that is, $\mathrm{pH}$ is advantageous for the formation of hydroxyapatite. As a result, the maximum compressive strength is assumed to be obtained for the highest $\mathrm{pH} 8.3$.

It should be, however, noted that the strength of the cement is not necessarily parallel to the absolute amount of the hydroxyapatite formed in the cement as shown in the comparison of Fig. 3 with Fig. 6. This may be explained by assuming that the average intergranular distance decreases as the $P / L$ ratio increases. As a result, the connection between glass powder granules through the hydroxyapatite layers formed at intergranular spaces becomes closer with increasing the $P / L$ ratio, giving the highest compressive strength for the mixture of the highest $P / L$ ratio of $1 \mathrm{~g} / 0.5 \mathrm{ml}$. In conclusion, the higher phosphate ion concentration, $\mathrm{pH}$ and the $P / L$ ratio are desirable for the present bioactive cement to obtain high mechanical strength.

Acknowledgement This work was supported by the Grant-inAid for Scientific Research from Ministry of Education, Science and Culture, Japan.

\section{References}

1) L. C. Chow, Seramikkusu Ronbunshi, 99, 954-64 (1991).

2) T. Kokubo, S. Yoshihara, N. Nishimura, T. Yamamuro and T. Nakamura, J. Am. Ceram. Soc., 74, 1739-41 (1991).

3) N. Nishimura, T. Yamamuro, Y. Taguchi, M. Ikenaga, T. Nakamura, T. Kokubo and S. Yoshihara, J. Appl. Biomater., 2, 219-29 (1991).

4) N. Nishimura, Y. Taguchi, T. Yamamuro, T. Nakamura, T. Kokubo and S. Yoshihara, J. Appl. Biomater., 4, 29-38 (1993).

5) S. Yoshihara, T. Kokubo, N. Nishimura, T. Yamamuro and T. Nakamura, J. Mater. Sci.; Materials in Medicine, 5, 123-29 (1994).

6) T. Kokubo, H. Kushitani, S. Sakka, T. Kitsugi and T. Yamamuro, J. Biomed. Mater. Res., 24, 721-34 (1990).

7) J. Gamble, "Chemical Anatomy, Physiology and Pathology of Extracellular Fluid”, 6th ed., Harvard University Press, Cambridge, MA (1967) p. 1.

8) T. Kokubo, S. Ito, Z. Huang, T. Hayashi, T. Shibuya and T. Yamamuro, J. Biomed. Mater. Res., 24, 331-43 (1990). 